\title{
Dielectric behaviour of sodium and potassium doped magnesium titanate
}

\author{
VISHNU SHANKER*, SANTOSH KUMAR and T SURENDAR \\ Department of Chemistry, National Institute of Technology, Warangal 506 004, India
}

MS received 10 November 2011; revised 27 February 2012

\begin{abstract}
Pure phase of magnesium titanate $\left(\mathrm{MgTiO}_{3}\right)$ was obtained at $1100^{\circ} \mathrm{C}$ by both the conventional solid-state method as well as by the flux method starting from hexahydrated magnesium nitrate and titanium dioxide as the reactants. $\mathrm{MgTiO}_{3}$ doped with $\mathrm{Na}$ or $\mathrm{K}$ was also prepared by the solid-state route. $\mathrm{Na}$ and $\mathrm{K}$ doped compositions led to monophasic $\mathrm{MgTiO}_{3}$ below $5 \mathrm{~mol} \%$ dopant concentration while biphasic mixture of $\mathrm{MgTiO}_{3}$ (major phase) and $\mathrm{MgTi}_{2} \mathrm{O}_{5}$ (minor phase) were obtained at higher dopant concentration. The dielectric constant and dielectric loss of $\mathrm{MgTiO}_{3}$ were found to be almost the same irrespective of the preparative method. $\mathrm{MgTiO}_{3}$ doped with 5 mol \% of $\mathrm{Na}$ and $\mathrm{K}$ ions displayed optimum dielectric properties.
\end{abstract}

Keywords. Ceramics; dielectric constant; dielectric loss.

\section{Introduction}

Magnesium titanate is one of the most widely used materials as resonators at microwave frequencies (Tamura and Katsube 1980). These resonators are widely used in filters and oscillators in microwave communication systems (Kell et al 1973; Plourde and Ren 1981; Wakino 1989; Subba Rao et al 1990; Wakino et al 1990). In earlier reports on synthesis of $\mathrm{MgTiO}_{3}$ by the solid-state method using oxides of magnesium and titanium, a secondary phase of $\mathrm{MgTi}_{2} \mathrm{O}_{5}$ was obtained which was very difficult to remove from the reaction product (Cambier et al 1982). Dielectric losses are influenced by the presence of lattice defects (vacancies, dislocations, impurities), secondary phase and porosity (Iddles et al 1992; Nomura 1983; Heiao et al 1988; Sato et al 1981; Ferreira et al 1992). To reduce the dielectric loss it is, therefore, important to prepare magnesium titanate without impurity. Several low temperature routes like the Pechini method have been used earlier to prepare pure $\mathrm{MgTiO}_{3}$ (Ferreira and Baptista 1994). The study of various dopants ( $\mathrm{La}, \mathrm{Cr}, \mathrm{Fe}, \mathrm{Co}$ and $\mathrm{Ni}$ ) in $\mathrm{MgTiO}_{3}$ has earlier shown that they may affect sintering behaviour and also dielectric loss of the materials (Ferreira et al 1992; Ferreira and Baptista 1994; Huang and Weng 2001).

In this paper, nitrate salt of magnesium was chosen as a starting material for the preparation of pure phase of magnesium titanate via the solid-state method and the molten salt (flux) method. In addition, we have also synthesized $\mathrm{MgTiO}_{3}$ doped with 1-10 mol \% of $\mathrm{Na}$ and $\mathrm{K}$ ions. We have also discussed the dielectric properties of undoped and doped (with

\footnotetext{
*Author for correspondence (vishnu@ nitw.ac.in)
}

$\mathrm{Na}$ and K) magnesium titanates on sintered disc at much lower sintering temperatures.

\section{Experimental}

The starting materials, $\mathrm{Mg}\left(\mathrm{NO}_{3}\right)_{2} \cdot 6 \mathrm{H}_{2} \mathrm{O}$ (Merck 99\%), and $\mathrm{TiO}_{2}$ (Fluka 99\%), $\mathrm{Na}_{2} \mathrm{CO}_{3}$ (Merck 99\%) and $\mathrm{K}_{2} \mathrm{CO}_{3}$ (Merck 99\%) were taken in their stoichiometric ratio for the synthesis of undoped and $(\mathrm{Na}, \mathrm{K})$-doped $\mathrm{MgTiO}_{3}$. Pure phase of $\mathrm{MgTiO}_{3}$ was prepared by both flux and solid-state methods. For ( $\mathrm{Na}, \mathrm{K}$ )-doped compositions, only the solid-state method was used. In the preparation of $\mathrm{MgTiO}_{3}$ by flux method, stoichiometric amount of $\mathrm{Mg}\left(\mathrm{NO}_{3}\right)_{2} \cdot 6 \mathrm{H}_{2} \mathrm{O}$ and $\mathrm{TiO}_{2}$ were taken along with a eutectic mixture $(1: 1)$ of $\mathrm{NaCl}$ and $\mathrm{KCl}$ in the ratio of 2:1. The mixture of reactants and flux was homogenized in an agate mortar and then loaded in alumina crucibles for heating at $900^{\circ} \mathrm{C}$ for $6 \mathrm{~h}$. The precursor was then washed several times with chloride-free hot double distilled water to remove the flux. The dried powder (at $110^{\circ} \mathrm{C}$ ) was further heated at $1000^{\circ} \mathrm{C}$ for $20 \mathrm{~h}$ and $1100^{\circ} \mathrm{C}$ for $24 \mathrm{~h}$ with intermittent grinding. Stoichiometric ratio of $\mathrm{Mg}\left(\mathrm{NO}_{3}\right)_{2} \cdot 6 \mathrm{H}_{2} \mathrm{O}$ and $\mathrm{TiO}_{2}$ were taken for the preparation of magnesium titanate by solid-state method. The mixture was properly homogenized in an agate mortar. The homogenized mixture was loaded in an alumina crucible and kept in the programmable furnace for heating at $900^{\circ} \mathrm{C}$ for $12 \mathrm{~h}$. The sample was further heated at $1025^{\circ} \mathrm{C}$ for $19 \mathrm{~h}$ and at $1100^{\circ} \mathrm{C}$ for $10 \mathrm{~h}$. Magnesium titanate doped with sodium and potassium was also synthesized by the solid-state method by using $\mathrm{Na}_{2} \mathrm{CO}_{3}$ and $\mathrm{K}_{2} \mathrm{CO}_{3}$ as the source of dopants. Powdered samples of undoped and doped magnesium titanate were treated with a 5\% polyvinyl alcohol (PVA) solution and then compacted into disks by applying uniaxial pressure of 8 tonnes. The compacted disks were sintered at $1100^{\circ} \mathrm{C}$ for $12 \mathrm{~h}$. Powder X-ray diffraction (PXRD) studies 
of the compounds were carried out after every stage of heating on a Bruker D8 Advance X-ray diffractometer with a step size of $0.05^{\circ}$ and a scan speed of $1 \mathrm{~s}$ per step in the 2 theta range of $10^{\circ}$ to $70^{\circ}$. The refined lattice parameters were obtained by a least-square fit to the observed $d$-values. Scanning electron micrographs (SEM) were obtained on the sintered disks (at $1100^{\circ} \mathrm{C}$ ) using a Cambridge Stereoscan 360 electron microscope in order to study grain size and morphology of the sample. The dielectric properties were measured on sintered pellets (coated on both sides with Ag-paste to act as electrodes) using an HP 4284L LCR meter in the frequency range $50-500 \mathrm{kHz}$ with varying temperatures from room temperature to $200^{\circ} \mathrm{C}$. The density of sintered pellets of undoped and doped magnesium titanate was measured using the Archimedes method and found in the range of $92-94 \%$ of theoretical density.

\section{Results and discussion}

Magnesium titanate was prepared by using hexahydrated magnesium nitrate by both solid-state and flux methods. The sodium and potassium doped compositions of magnesium titanate were prepared by the solid-state method. In the synthesis using flux, a minor impurity phase was present along with the major phase of $\mathrm{MgTiO}_{3}$ after the initial reaction at $900^{\circ} \mathrm{C}$. Further heating at $1000^{\circ} \mathrm{C}$ for $20 \mathrm{~h}$ and $1100^{\circ} \mathrm{C}$ for $12 \mathrm{~h}$ led to pure phase of $\mathrm{MgTiO}_{3}$ (figure 1a). The solid-state method led to the formation of a biphasic mixture containing $\mathrm{MgTi}_{2} \mathrm{O}_{5}(15 \%)$ along with the major phase $\left(\mathrm{MgTiO}_{3}\right)$ after heating the homogenized sample at $900^{\circ} \mathrm{C}$ for $12 \mathrm{~h}$. On further heating at $1025^{\circ} \mathrm{C}$ for $20 \mathrm{~h}$ a pure phase of $\mathrm{MgTiO}_{3}$ was obtained. The oxides were sintered at $1100^{\circ} \mathrm{C}$ for $12 \mathrm{~h}$ and were found to be monophasic (figure $1 \mathrm{~b}$ ). It may be
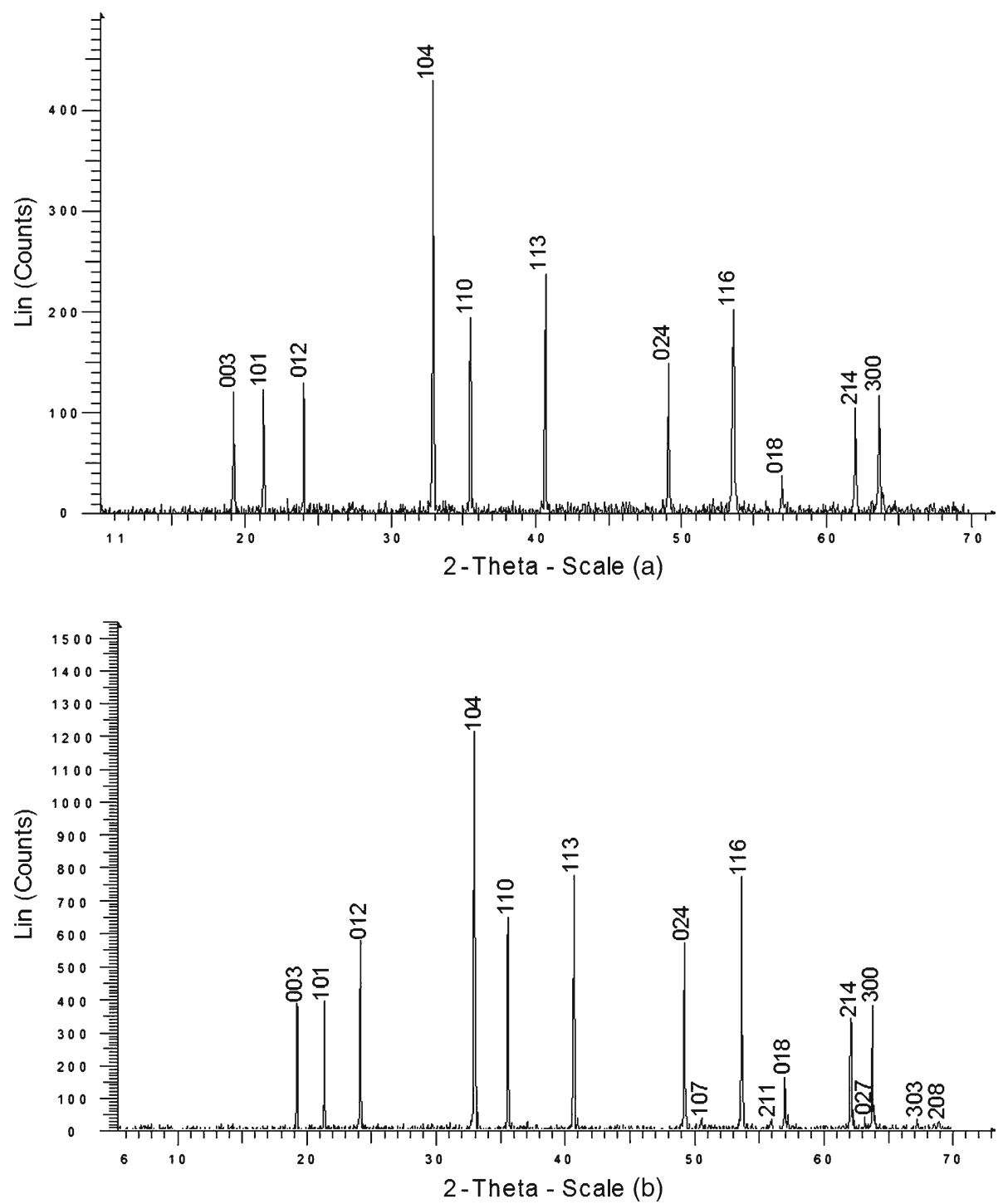

Figure 1. Powder X-ray diffraction pattern of $\mathrm{MgTiO}_{3}$ prepared by (a) flux method and (b) solid-state method after $1100^{\circ} \mathrm{C}$ heating. 
noted that the solid-state route to $\mathrm{MgTiO}_{3}$ (from $\mathrm{MgO}$ and $\mathrm{TiO}_{2}$ ) always yields a small percentage of $\mathrm{MgTi}_{2} \mathrm{O}_{5}$ as secondary phase even at elevated temperatures. However, we have avoided formation of the $\mathrm{MgTi}_{2} \mathrm{O}_{5}$ using $\mathrm{Mg}\left(\mathrm{NO}_{3}\right)_{2} \cdot 6 \mathrm{H}_{2} \mathrm{O}$ rather than $\mathrm{MgO}$. In case of doped magnesium titanate compositions prepared by solid-state method

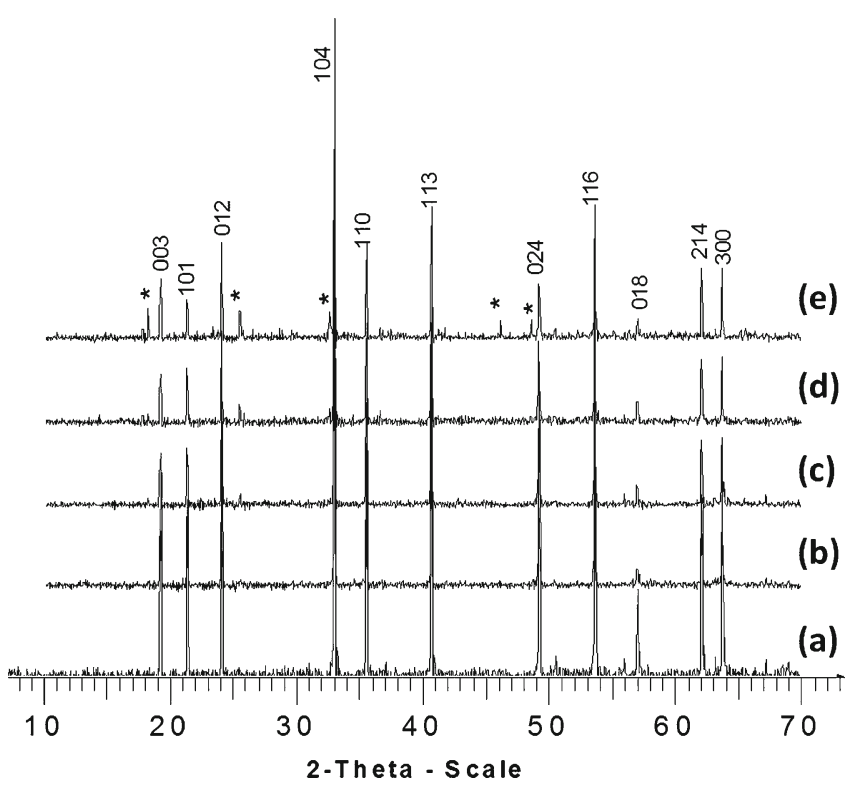

Figure 2. Powder X-ray diffraction pattern of (a) undoped $\mathrm{MgTiO}_{3}$, (b) $1 \% \mathrm{Na}$, (c) $2 \% \mathrm{Na}$, (d) $5 \% \mathrm{Na}$ and (e) $10 \% \mathrm{Na}$ prepared by solid-state method at $1100^{\circ} \mathrm{C}$.

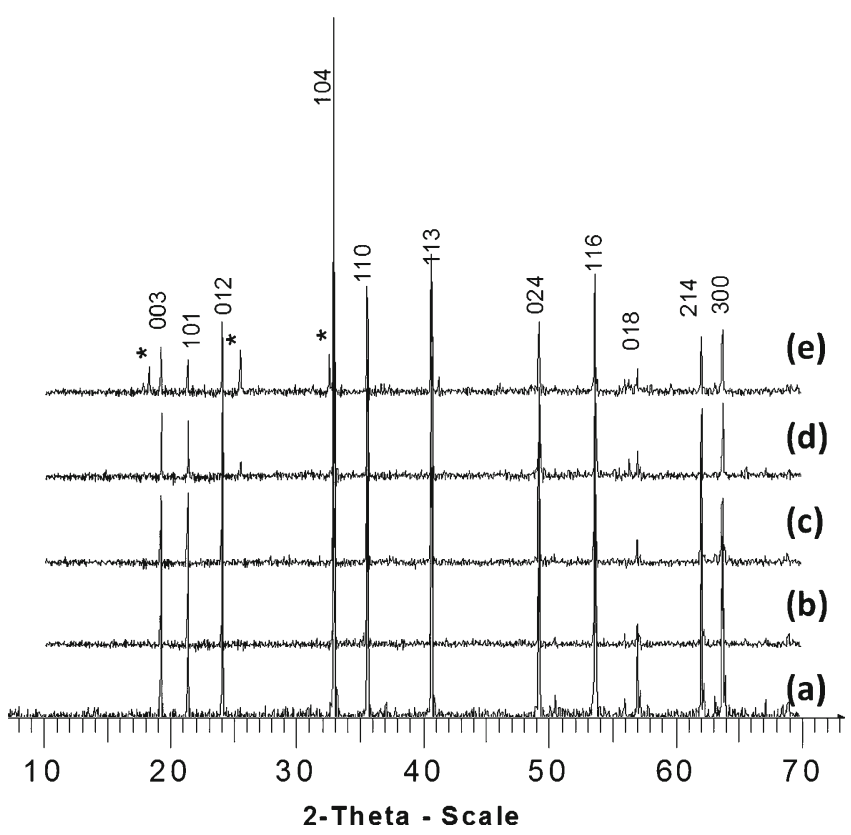

Figure 3. Powder X-ray diffraction pattern of (a) undoped $\mathrm{MgTiO}_{3}$, (b) $1 \% \mathrm{~K}$, (c) $2 \% \mathrm{~K}$, (d) $5 \% \mathrm{~K}$ and (e) $10 \% \mathrm{~K}$ prepared by solid-state method at $1100^{\circ} \mathrm{C}$. at $1100^{\circ} \mathrm{C}$, pure phase of $\mathrm{MgTiO}_{3}$ was observed for $1 \mathrm{~mol} \%$ $\mathrm{Na}$ dopant whereas in $\mathrm{K}$ doped composition it was observed at 1 and 2 mol \% dopants. The secondary phase of $\mathrm{MgTi}_{2} \mathrm{O}_{5}$ appeared at higher dopant concentration $(5 \mathrm{~mol} \%)$ and the secondary phase was increasing with increased dopant concentration (figures 2 and 3). PXRD pattern for pure $\mathrm{MgTiO}_{3}$ could be indexed satisfactorily in the hexagonal cell as is known for the ilmenite structure of $\mathrm{MgTiO}_{3}(\mathbf{a} \sim 5.05 \AA$ and c $13.86 \AA$ ).

Scanning electron micrographs (SEM) of $\mathrm{MgTiO}_{3}$ prepared by the flux method and solid-state method were recorded of sintered sample at $1100^{\circ} \mathrm{C}$. The micrographs show that the grain boundaries are better defined in the oxide obtained by the solid-state route (figure $4 \mathrm{~b}$ ). The grain size was found to be 2-4 $\mathrm{mm}$ (figures $4 \mathrm{a}$ and $\mathrm{b}$ ). SEM studies on sintered (at $1100^{\circ} \mathrm{C}$ ) sample of doped $(\mathrm{Na}, \mathrm{K})-\mathrm{MgTiO}_{3}$ shows that grain size increases $(\sim 5 \mu \mathrm{m})$ as concentration of dopant increases up to $2 \mathrm{~mol} \%$ (figures $5 \mathrm{~b}$ and $6 \mathrm{~b}$ ). However, further increasing the dopant concentration (5 mol \%) leads to smaller grains $(\sim 2-3 \mu \mathrm{m})$. However, these grains are dense and have well developed facets (figures $5 \mathrm{c}$ and $6 \mathrm{c}$ ). The secondary phase $\left(\mathrm{MgTi}_{2} \mathrm{O}_{5}\right)$, which is clear from PXRD
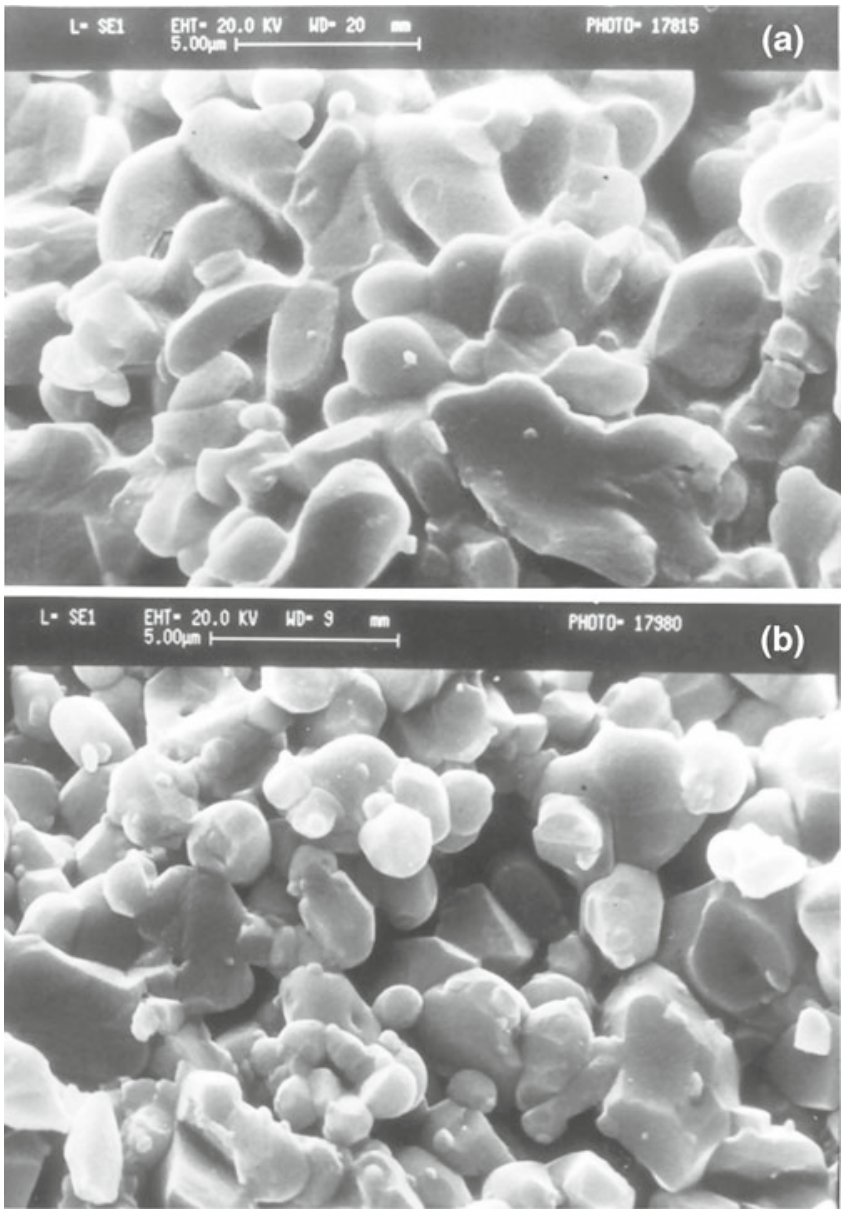

Figure 4. Scanning electron micrograph of $\mathrm{MgTiO}_{3}$ sintered at $1100^{\circ} \mathrm{C}$ synthesized by (a) flux method and (b) solid-state method. 

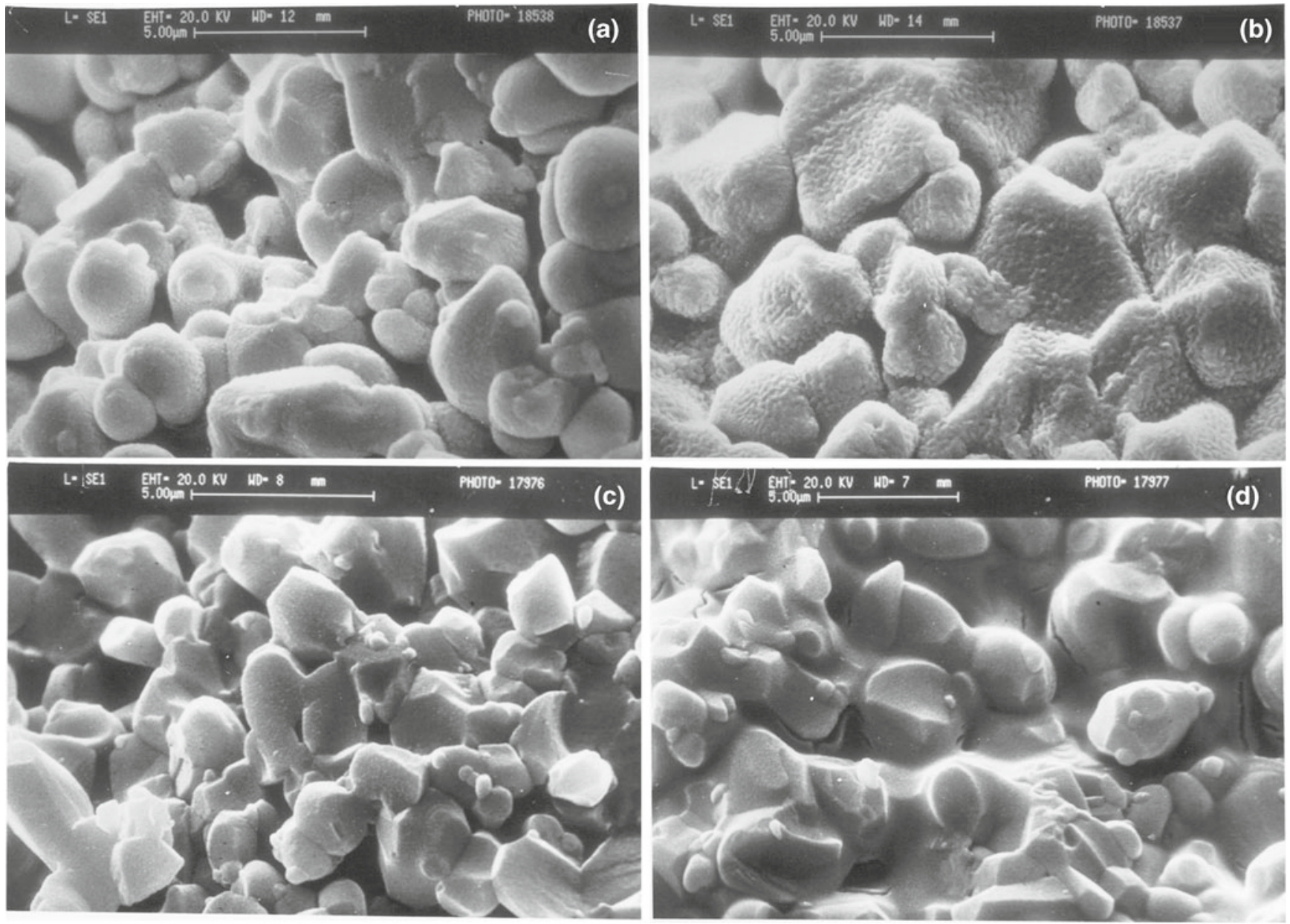

Figure 5. Scanning electron micrograph of sintered disk of (a) $1 \mathrm{~mol} \%$, (b) $2 \mathrm{~mol} \%$, (c) $5 \mathrm{~mol} \%$ and (d) $10 \mathrm{~mol} \% \mathrm{Na}$ doped $\mathrm{MgTiO}_{3}$ at $1100^{\circ} \mathrm{C}$.

pattern, seems to appear at higher (10 mol \%) dopant concentrations (figures $5 \mathrm{~d}$ and $6 \mathrm{~d}$ ). These studies clearly show that the grain size increased as the percentage of $\mathrm{Na}$ and $\mathrm{K}$ dopants increased. The grain boundaries were also well defined in the doped magnesium titanate. The grain sizes of all the compounds have been given in table 1 .

Measurement of dielectric properties of all the compounds, pure and doped $\mathrm{MgTiO}_{3}$, was carried out on disks sintered at $1100^{\circ} \mathrm{C}$ in the temperature range from room temperature to $200^{\circ} \mathrm{C}$. The variation of dielectric constant and dielectric loss with frequency in the range of $50 \mathrm{~Hz}$ to $500 \mathrm{kHz}$ at room temperature are shown in figures $7 \mathrm{a}$ and $\mathrm{b}$. The dielectric constant $(\varepsilon)$ obtained was 14.8 and dielectric loss $(D)$ was 0.0004 at $100 \mathrm{kHz}$ for $\mathrm{MgTiO}_{3}$ synthesized by the flux route and was quite similar to $\mathrm{MgTiO}_{3}$ obtained by the solid-state method. The dielectric constant $(\varepsilon)$ was stable in the entire range of frequencies irrespective of the preparative method. The dielectric loss $(D)$ shows stability in the frequency range of 10-200 kHz. However, there is an increase in the dielectric loss beyond $300 \mathrm{kHz}$ till $500 \mathrm{kHz}$, which may suggest a well-defined loss peak at higher frequencies (figures $7 \mathrm{a}$ and $\mathrm{b}$ ). The dielectric constant was highly stable in the entire temperature range from room temperature to $200^{\circ} \mathrm{C}$, for $\mathrm{MgTiO}_{3}$ prepared by either method (flux and solid-state) and is shown in figures $8 \mathrm{a}$ and $\mathrm{b}$. The behaviour of dielectric properties of doped magnesium titanate with increase in the percentage of $\mathrm{Na}$ and $\mathrm{K}$ as dopants are shown in figures $9 \mathrm{a}$ and $\mathrm{b}$. The dielectric constant was found to be maximum for $5 \mathrm{~mol} \%$ of dopant. However, dielectric loss was higher for $1 \mathrm{~mol} \%$ of $\mathrm{Na}$ doped magnesium tiatnate whereas in $\mathrm{K}$ dopant it was higher at 2 mol \% composition. It is interesting to note that the variation of the dielectric constant with mol \% of either ' $\mathrm{Na}$ ' or ' $\mathrm{K}$ ' is nearly identical. The initial decrease (minimum $\varepsilon$ at $2 \mathrm{~mol} \%$ ) and then increase (maximum $\varepsilon$ at $5 \mathrm{~mol} \%$ ) occurs for both the dopants (figure 9a). It may be noted that at higher concentration of dopant (5-10\%), the secondary phase $\mathrm{MgTi}_{2} \mathrm{O}_{5}$ starts forming. $\mathrm{MgTi}_{2} \mathrm{O}_{5}$ synthesized by the solid-state route under similar conditions as the other oxides discussed above, shows a dielectric constant of $\sim 16$ and loss of 0.04 at $100 \mathrm{kHz}$. The observed $\varepsilon$ values at $5 \mathrm{~mol} \%$ of $\mathrm{Na}$ and $\mathrm{K}$ dopants are much higher (18-21) than that observed for pure $\mathrm{MgTiO}_{3}(\sim 15)$ and that of $\mathrm{MgTi}_{2} \mathrm{O}_{5}$ (16). It appears that the grains are very densely packed at $5 \mathrm{~mol} \%$ of dopant 

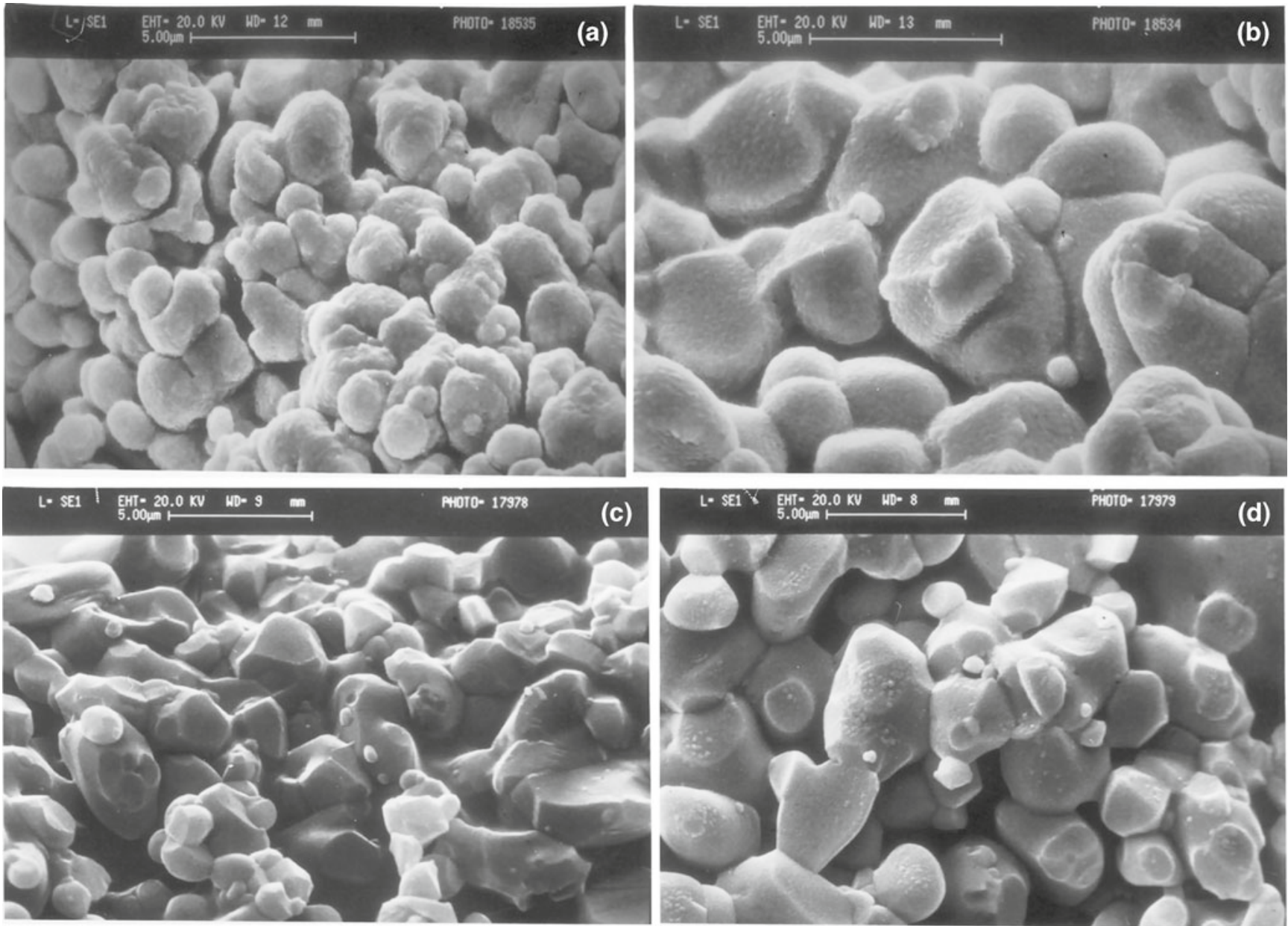

Figure 6. Scanning electron micrograph of sintered disk of (a) $1 \mathrm{~mol} \%$, (b) $2 \mathrm{~mol} \%$, (c) $5 \mathrm{~mol} \%$ and (d) $10 \mathrm{~mol} \% \mathrm{~K} \mathrm{doped} \mathrm{MgTiO}_{3}$ at $1100^{\circ} \mathrm{C}$.

Table 1. Details of doped $\mathrm{MgTiO}_{3}$ synthesized by solid-state route.

\begin{tabular}{|c|c|c|c|c|}
\hline $\begin{array}{l}\text { Dopant } \\
\text { concentration }\end{array}$ & $\begin{array}{l}\text { Secondary } \\
\text { phase }\end{array}$ & $\begin{array}{c}\varepsilon \\
(100 \mathrm{kHz})\end{array}$ & $\begin{array}{c}D \\
(100 \mathrm{kHz})\end{array}$ & $\begin{array}{l}\text { Grain size } \\
\qquad(\mu \mathrm{m})\end{array}$ \\
\hline None* & - & $14 \cdot 8$ & 0.0004 & $2 \cdot 5-3 \cdot 5$ \\
\hline None & - & $15 \cdot 0$ & 0.00048 & $2-4$ \\
\hline $1 \mathrm{~mol} \% \mathrm{Na}^{+}$ & - & $14 \cdot 0$ & 0.002 & $2-4$ \\
\hline $2 \mathrm{~mol} \% \mathrm{Na}^{+}$ & $7 \% \mathrm{MgTi}_{2} \mathrm{O}_{5}$ & $10 \cdot 8$ & 0.0016 & $3-6$ \\
\hline $5 \mathrm{~mol} \% \mathrm{Na}^{+}$ & $7 \% \mathrm{MgTi}_{2} \mathrm{O}_{5}$ & $18 \cdot 1$ & 0.0009 & $2-3 \cdot 5$ \\
\hline $10 \mathrm{~mol} \% \mathrm{Na}^{+}$ & $26 \% \mathrm{MgTi}_{2} \mathrm{O}_{5}$ & $15 \cdot 4$ & 0.00046 & $4-5$ \\
\hline $1 \mathrm{~mol} \% \mathrm{~K}^{+}$ & - & $13 \cdot 2$ & 0.00078 & $1 \cdot 5-3$ \\
\hline $2 \mathrm{~mol} \% \mathrm{~K}^{+}$ & - & $10 \cdot 9$ & 0.0012 & $3-6$ \\
\hline $5 \mathrm{~mol} \% \mathrm{~K}^{+}$ & $9 \% \mathrm{MgTi}_{2} \mathrm{O}_{5}$ & $21 \cdot 2$ & 0.00047 & $1 \cdot 5-3 \cdot 5$ \\
\hline $10 \mathrm{~mol} \% \mathrm{~K}^{+}$ & $21 \% \mathrm{MgTi}_{2} \mathrm{O}_{5}$ & $14 \cdot 2$ & 0.00052 & $3-5$ \\
\hline
\end{tabular}

* Prepared by flux method.

concentration as observed in SEM (figures $5 \mathrm{c}$ and $6 \mathrm{c}$ ) and are well faceted. It may also be seen that the loss is quite low for this dopant concentration. Both the high dielectric constant and low loss may be rationalized by the well-sintered nature of the grains of this material containing $5 \mathrm{~mol} \%$ of dopant. The minimum $\varepsilon$ found at $2 \mathrm{~mol} \%$ doping may also be correlated with the microstructure. SEM images of $2 \mathrm{~mol} \%$ doping (figures $5 \mathrm{~b}$ and $6 \mathrm{~b}$ ) show large grains where the surface morphology is very different from the well faceted grain obtained at $5 \mathrm{~mol} \%$ of dopant (figures $5 \mathrm{c}$ and $6 \mathrm{c}$ ). This 



Figure 7. Variation of dielectric constant $(\varepsilon)$ and dielectric loss (D) with frequency at room temperature for $\mathrm{MgTiO}_{3}$ prepared by (a) flux method and (b) solid-state method.
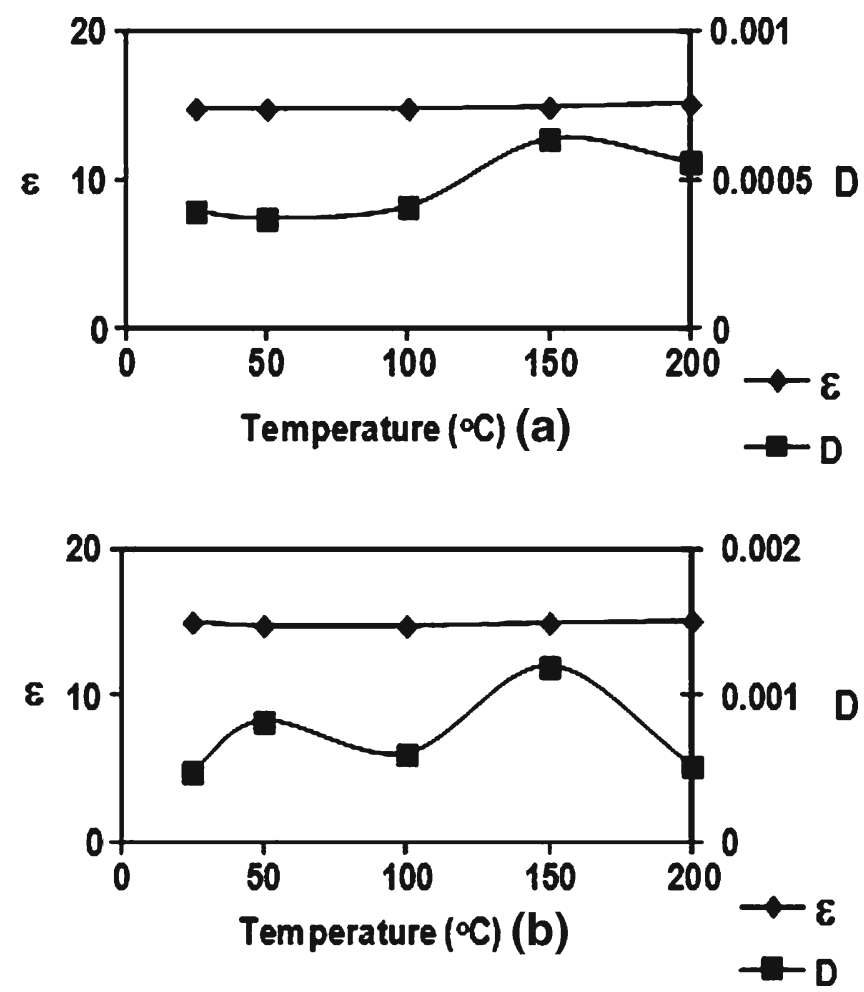

Figure 8. Variation of dielectric constant $(\varepsilon)$ and dielectric loss $(D)$ at $100 \mathrm{kHz}$ with temperature for $\mathrm{MgTiO}_{3}$ prepared by (a) flux method and (b) solid-state method.
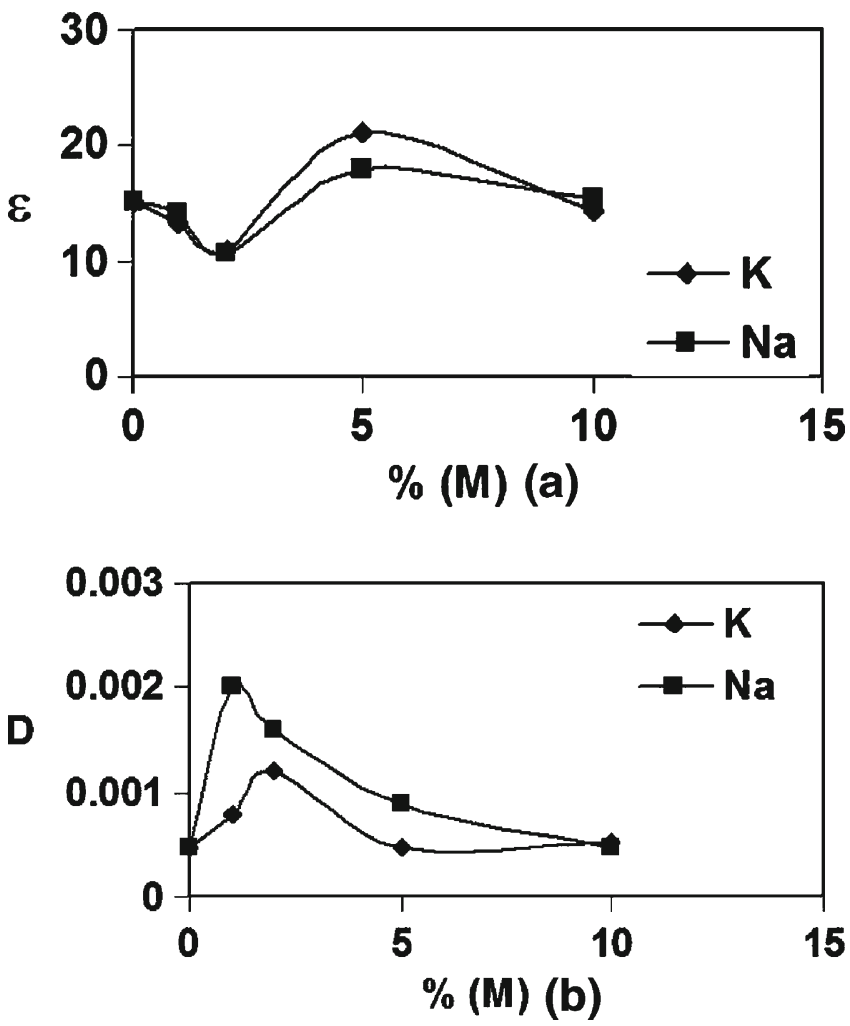

Figure 9. Variation of (a) dielectric constant $(\varepsilon)$ and (b) dielectric loss $(D)$ with mol \% of dopant concentration $(M)$ at $100 \mathrm{kHz}$.

may be due to small grains covering surface of the large grains. The different microstructures obtained may be due to difference in liquid phase wetting at the higher dopant concentrations.

\section{Conclusions}

We could obtain pure phase of $\mathrm{MgTiO}_{3}$ using $\mathrm{Mg}\left(\mathrm{NO}_{3}\right) \cdot 6 \mathrm{H}_{2} \mathrm{O}$ by both the flux and solid-state methods with the absence of $\mathrm{MgTi}_{2} \mathrm{O}_{5}$, an inevitable secondary phase in the solid-state synthesis of $\mathrm{MgTiO}_{3}$. The dielectric loss was found to be almost the same in undoped $\mathrm{MgTiO}_{3}$ irrespective of the preparative method. However, a small increase in the dielectric constant was observed in undoped $\mathrm{MgTiO}_{3}$ obtained by solid-state method. The optimal dopant concentration ( $5 \mathrm{~mol} \%$ ) leads to higher dielectric constant and lower loss irrespective of the doped metal ion ( $\mathrm{Na}$ or $\mathrm{K})$. This is probably due to the increased sinterability of materials obtained at such dopant levels.

\section{Acknowledgement}

The authors thank the Indian Institute of Technology, Delhi, for according permission to carry out characterization of the samples. 


\section{References}

Cambier F, Leblud C and Anseau M R 1982 Ceram. Int. 877 Ferreira V M and Baptista J L 1994 Mater. Res. Bull. 291017 Ferreira V M, Azough F, Baptista J L and Freer R 1992 Ferroelectrics 133127

Heiao Y C, Wu L and Wei C C 1988 Mater. Res. Bull. 23687

Huang C L and Weng M H 2001 Mater. Res. Bull. 362741

Iddles D M, Bell A J and Moulson A J 1992 J. Mater. Sci. 271603

Kell R C, Greenham A C and Olds G C E 1973 J. Am. Ceram. Soc. 56352
Nomura S 1983 Ferroelectrics 4961

Plourde J K and Ren C L 1981 IEEE Trans. Microwave Theory and Techniques 29754

Sato T, Miyamoto R and Fukasawa A 1981 Jap. J. Appl. Phys. 2060

Subba Rao T, Murthy V R K and Viswanathan B 1990 Ferroelectrics 102155

Tamura H and Katsube M 1980 U. S. Patent 4224213

Wakino K 1989 Ferroelectrics 9166

Wakino K, Nishikawa T, Nishikawa Y and Tamura H 1990 Br. Ceram. Trans. J. 8939 